\title{
Optimal Urban Logistics - Through the Choice of Sustainable Axes
}

\author{
Fadwa Farchi $^{1 *}$, Badr Touzi ${ }^{2}$, Chayma Farchi ${ }^{1}$, Charif Mabrouki $^{1}$ \\ ${ }^{1}$ Department of Mechanical and Electrical Engineering, Hassan 1er University of Settat, Settat 26000, Morocco \\ ${ }^{2}$ Department of Economics and Management Sciences, Mohammed V University of Rabat, Rabat 10170, Morocco
}

Corresponding Author Email: f.farchi@uhp.ac.ma

https://doi.org/10.18280/ijsdp.160815

Received: 6 July 2021

Accepted: 17 December 2021

\section{Keywords:}

urban logistics, smart city, sustainable urban logistics, digitization, stakeholders, literature review

\begin{abstract}
In a world where urbanization is becoming more and more widespread, big figures can be seen around internal urban migration further aggravating the environmental urban situation, which results from several previous factors. This is the case with globalization, online shopping, or polluting industrial and human sources. The major solutions are centered primarily on the concern for urban mobility, the involvement of the stakeholders concerned, the optimization of journeys, the use of lanes and roads, the choice of vehicles as well as the zoning or choice of logistics locations. Sustainability is one of the primary elements of flow management; it is one of the most important pillars of the concept of "urban logistics". Indeed, the final goal goes beyond the delivery of goods, going so far as to place the environment as an essential support for urban logistics. In this paper we present a literature review on sustainable logistics, we will try to answer the following problem: Urban logistics: Where are we? To respond to this problem, we are taking the following approach: Presentation of the basic concepts, choice of articles to be used for the study which will induce us to determine the axes and the main actors, with the aim of specifying the most predominant aspects which must be treated and prioritized in order to make urban logistics more optimal.
\end{abstract}

\section{INTRODUCTION}

The future vision or the "Smart city" is a framework for the development strategy of urban centers, which integrate several levels of development.

The global atmospheric situation is constantly deteriorating, and awareness of this unfavorable balance remains a challenge for all stakeholders. Manufacturers are the first to be targeted, whether in terms of internal production or the distribution part, the two axes present very high pollution numbers. It is in this sense that urban logistics is involved in this sustainable approach due to the complication of urban mobility and traffic.

Concretely, with the aim of optimizing the management of freight transport on the one hand, and reducing the negative impacts on the other hand (congestion, air pollution, noise pollution, non-respect of the safety of goods and people) urban logistics as a concept, is subject to several constraints of expectation and reality. The solutions proposed are diverse but cannot be transposed from one diagram to another. Consequently, urban logistics will have to be able to respond to contradictory constraints related to the economy, sustainability, urban planning (also institutional side) and especially good logistics management.

Through a selective logic of articles, the aim of this latter is to respond to the problem of optimizing transport in urban areas. The solution we propose is the detection of the most important axes on which we will work in a later time.

\section{THE DEFINITIONS OF URBAN LOGISTICS}

The term "last mile" originated in the telecommunications industry. Now, last mile logistics are assigned to the last link in a delivery process [1], which is often considered the most expensive and least efficient aspect of a supply chain Macharis et al. [2].

To consolidate urban logistics' definition, we offer some opinions from the authors around the concept of urban logistics [3]. We summarize this in Table 1 which will contain the authors' definitions around urban logistics:

Table 1. Authors' definitions

\begin{tabular}{|c|c|c|c|c|}
\hline Author & Definition & Contribution & Limit & Year \\
\hline $\begin{array}{l}\text { The } \\
\text { Organization } \\
\text { for Economic } \\
\text { Cooperation } \\
\text { and }\end{array}$ & $\begin{array}{l}\text { The delivery of consumer goods (not only at retail but also by other } \\
\text { sectors such as manufacturing) in cities and suburbs, including the } \\
\text { reverse flow of used goods in the form of clean waste. }\end{array}$ & $\begin{array}{l}\text { Transport of } \\
\text { goods in city }\end{array}$ & $\begin{array}{l}\text { Handling deliveries } \\
\text { and reverse logistics } \\
\text { only } \\
\text { Sustainability not } \\
\text { involved }\end{array}$ & 2003 \\
\hline
\end{tabular}




\begin{tabular}{|c|c|c|c|c|}
\hline $\begin{array}{c}\text { Taylor } \\
\text { Michael \& } \\
\text { Coll }\end{array}$ & $\begin{array}{l}\text { A system for managing the flow of goods and information at the level of } \\
\text { the city or its metropolitan area. It is "the process by which the logistics } \\
\text { and transport activities of private companies are optimized with the help } \\
\text { of advanced information systems for the management of traffic, its } \\
\text { congestion, security and energy resources in the areas' agglomerations, } \\
\text { within a market economy. }\end{array}$ & City logistics & $\begin{array}{l}\text { Customer } \\
\text { satisfaction }\end{array}$ & 2005 \\
\hline Dablanc & $\begin{array}{l}\text { Service contributing to an optimized management of the flow of goods in } \\
\text { an urban environment" }\end{array}$ & $\begin{array}{l}\text { Urban } \\
\text { logistics }\end{array}$ & $\begin{array}{l}\text { Passengers, } \\
\text { information \& } \\
\text { Sustainability not } \\
\quad \text { involved }\end{array}$ & 2005 \\
\hline Pipame & $\begin{array}{l}\text { Transport of goods in the heart of urban areas, their treatment in these } \\
\text { territories, their delivery to the final recipient as well as the management } \\
\text { of return flows (returned products, to be recycled and waste). It is } \\
\text { therefore the "last link" in the logistics chain, the most visible to end } \\
\text { consumers as one of the most expensive (around } 20 \% \text { of the total cost of } \\
\text { the logistics chain *). Indeed, urban space, which brings together a large } \\
\text { part of consumption, is also where the movement of goods is the most } \\
\text { difficult and complex. }\end{array}$ & $\begin{array}{c}\text { Logistics and } \\
\text { urban } \\
\text { distribution }\end{array}$ & $\begin{array}{l}\text { Sustainability not } \\
\text { involved }\end{array}$ & 2009 \\
\hline $\begin{array}{l}\text { Taniguchi \& } \\
\qquad \mathrm{Al}\end{array}$ & $\begin{array}{l}\text { The process of fully optimizing the logistics and transport activities of } \\
\text { private companies in urban areas while taking into account the traffic } \\
\text { environment, congestion and energy consumption within the framework } \\
\text { of a market economy }\end{array}$ & City logistics & $\begin{array}{l}\text { Reserved for private } \\
\text { companies }\end{array}$ & 2014 \\
\hline $\begin{array}{l}\text { Durand \& } \\
\text { Senkel }\end{array}$ & $\begin{array}{l}\text { Flows relating to deliveries and collections for the needs of commercial, } \\
\text { industrial or tertiary establishments in the private sector; } \\
\text { - Travel related to the supply of the end consumer (i.e. purchasing trips } \\
\text { but also new delivery practices at home or near the place of } \\
\text { consumption); } \\
\text { - Flows linked to urban management, mainly generated by the transport } \\
\text { of waste, the specific needs of public services, removals, home } \\
\text { deliveries, postal services, hospitals. }\end{array}$ & $\begin{array}{l}\text { Transport of } \\
\text { goods in town }\end{array}$ & $\begin{array}{l}\text { Sustainability not } \\
\text { involved }\end{array}$ & 2018 \\
\hline
\end{tabular}

\section{BIBLIOGRAPHIC STUDIES}

\subsection{Methodology}

3.1.1 Analysis of methodology and approaches

We will start with an analysis of axes in order to determine which ones are important, to then be able to recall certain important concepts in urban logistics.

Our work is a literature review. It then consists of studying the current state existing in urban logistics. To do so, we are going to create a database to be analyzed in order to position this last within a time, place and area frames, and to identify the primary axes that will improve the logistic state of cities afterwards.

When building our database, we encountered many research and analysis approaches and methodologies. Case studies remain the most predominant, followed by literature reviews as well as case reviews. Mass researches remain elementary. Note that about few approaches encountered only once have been neglected at the level of the graph. We briefly illustrate the symbolic types in Figure 1.

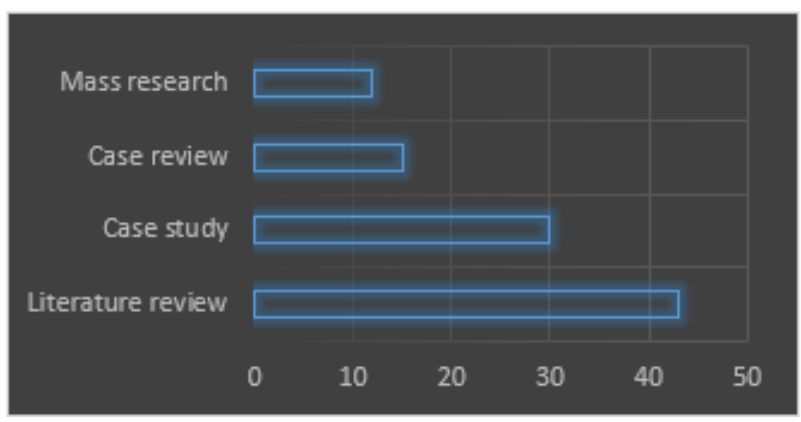

Figure 1. Proportion of methodologies
This processing only concerns the articles kept in our database. The following chapter shows how we created this database, the selection and sorting criteria.

\subsubsection{Selection of articles}

In order to constitute our database, we launched a synthesis study applied to last mile logistics. This latter relies mainly on bibliographic sources to visualize the subject in its entirety while broadening our field of reflection. This theoretical approach calls for varied and necessary readings to enrich our knowledge of concepts such as: the last mile, environmentally friendly means of transport, coordination, synergy and stakeholder involvement.

The ultimate objective of this documentary review is to answer the following problem: Urban logistics: Where are we? In order to answer this question, we have selected the best search engines: Elsevier, Science Direct and Google Scholar in order to bring together the maximum number of articles published between 2015 and 2021 (Case studies, interviews, literature review, case review) that deal with our subject. Initially, we tried to constitute a global sample around urban logistics made up of 546 articles. In a second step, we carried out a sorting based on the selection of a few key words (Freight, Urban logistics, Smart city, Urban freight, City logistics...) in order to rule out the articles which do not correspond to what we are looking for. As a last step we kept the articles which imply the sustainable side, a sample of 100 articles has been selected. Most of the articles - over $71 \%$ - discuss the importance of the viable aspect of sustainability.

Figure 2 below shows how we selected articles according to three primary criteria.

In what follows we will deal with the position, time and field sides of the retained articles to demonstrate what our database is made up of. 


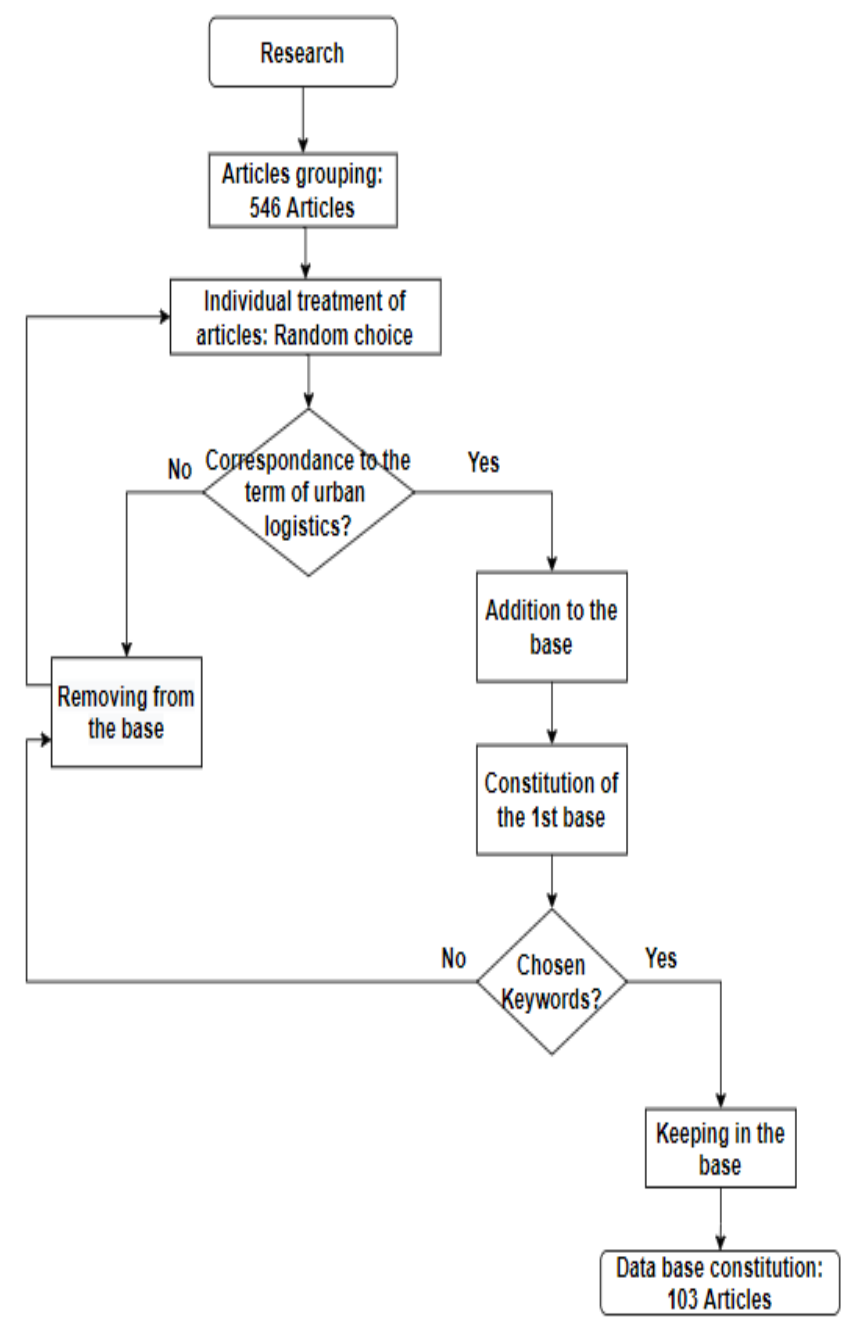

Figure 2. Flowchart selection of articles

\subsection{Data analysis}

Our database is composed of articles dating between 2015 and 2021. Mostly, we structured our database by articles published during the year 2020, with a share of 54\% (Figure $3)$.

Authors around the world have been drawn to the topic of urban logistics. However, China remains the country that publishes the most on urban logistics (Figure 4).

During the COVID-19 pandemic, China was one of the few countries that did not change their research trends or affiliate the latter in their scientific works.

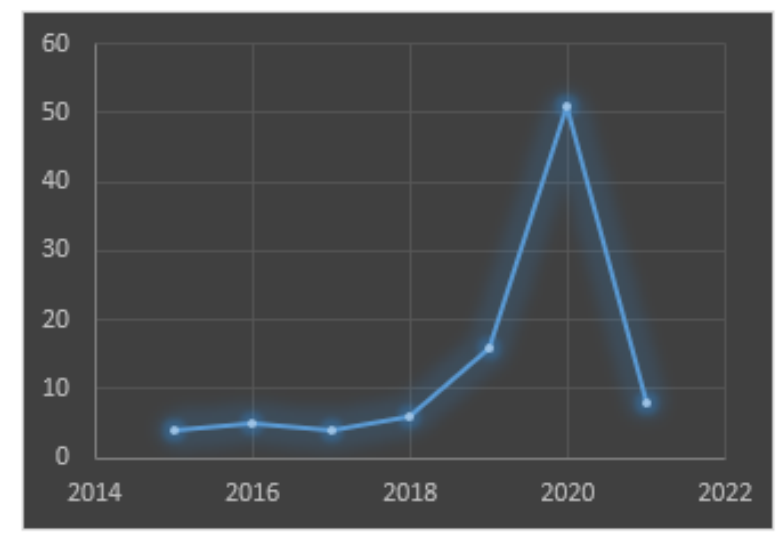

Figure 3. Years chart

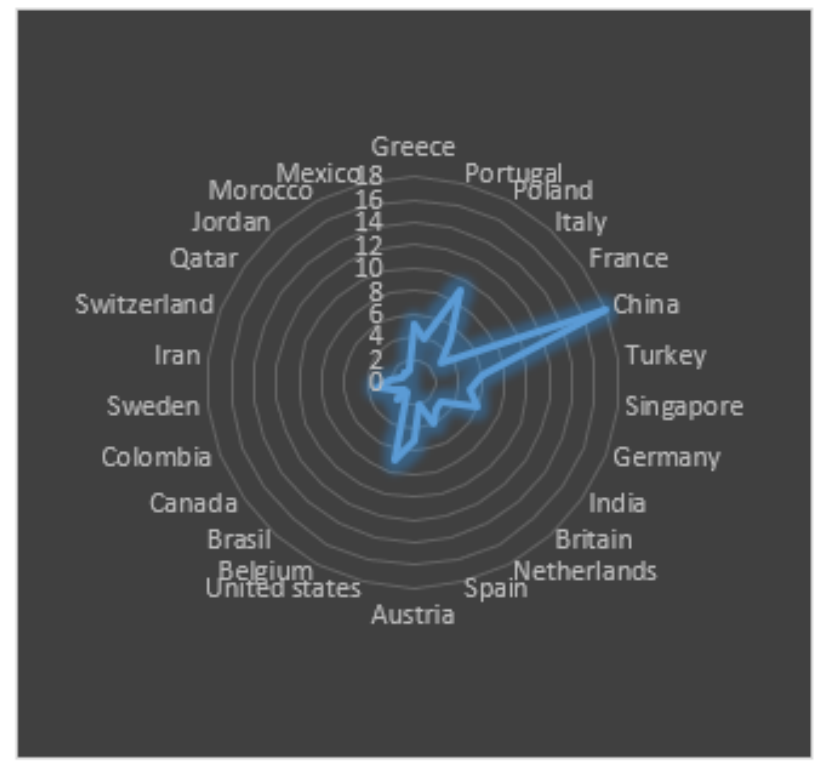

Figure 4. Country chart

Table 2. Proportion per field

\begin{tabular}{cc}
\hline Fields & Proportion \\
\hline FMGC Industry & $2 \%$ \\
E-Commerce & $6 \%$ \\
Construction & $2 \%$ \\
General & $8 \%$ \\
Omnichannel B2C Transport & $69 \%$ \\
Cold Chain & $2 \%$ \\
Intermodal Terminals & $2 \%$ \\
Uncertain Markets & $2 \%$ \\
Smart Logistics Zones & $2 \%$ \\
Logistics 4.0 & $2 \%$ \\
\hline
\end{tabular}

The articles that we have kept deal with a set of themes as shown in Table 2.

Almost $70 \%$ of the articles deal with urban logistics in a general and vague manner, while the contributions targeted and oriented towards a representative framework form only a mediocre percentage by area.

\section{URBAN LOGISTICS}

\subsection{Definition}

There are many definitions for urban logistics. However, they have certain limitations. Among the key concepts to be present in the definition are sustainability, the optimization aspect, the management of goods, passengers, information, as well as modes and means of transport.

Like traditional logistics to which we attach the management of global flows associated with industry - flows of good, people and information-, urban logistics is a particular element of the latter that covers the same scenario in the city. In other words, according to the opinions of others authors, ours and the direction of this research, we define urban logistics as follows: "It is the concretization of the content of classic logistics in terms of application and assistance with the aim of optimizing sustainably the management of freight, people and information in the long term at the level of the urban context: Main cities, peripheral areas, urbanized areas, and inter-city areas as well". In addition to these practices, 
there is control over the installation of urban logistics infrastructure, the careful choice of transport vehicles, coordination between the different actors and sustainable thinking.

\subsection{Pillars of urban logistics}

Knowledge of the correct functionality and the real purpose of urban logistics differs from one author to another and is based on a multitude of axes. The solutions proposed emanate from the environmental and infrastructural realities of each urban area and cannot, however, be transposed into different contexts.

Navarro et al. 2015 see that the use is E-cycles and the installation of transshipment points or micro-distribution platforms work best for the two cities of Barcelona and Valencia. This is also the case with Schliwa et al., 2015 or Nürnberg, 2018 who advocate cyclical logistics or cargo bikes [4-6].

Ruesch et al., 2019, believe that the choice of logistics areas should be the result of a whole multi-criteria analysis ranging from primary selection to the size of the logistics area. Gatta et al. 2017 examined the SMART planning process of freight transport according to 3 approaches: Desk approach, Living Lab approach and modeling approach $[7,8]$.

Tian et al., 2019 see that customer satisfaction assessment will need to be automated blockchain-based. Similarly, Giret, 2019, Drop et al., 2021 confirm the need to introduce smart techniques into urban logistics [9, 10].

Sabina Kauf, 2016 like Michael \& Coll, associates urban logistics with the notion of "SMART CITY" at a time when Morfoulaki et al, 2015 connect sustainable urban logistics with the correct evaluation of policy measures [11-13].

Clean last mile transport, according to Cossu [2016], depends on a large number of soft measures, cooperation between operators and stakeholder involvement (Lagorio et al., 2017) $[14,15]$.

Pimentel and Alvelos, 2018 prefer to group the transport of passengers and freight in an energy optimization framework, while Bergmann et al., 2019 consider the grouping of the first and last $\mathrm{km}$ better $[16,17]$.

In China, the use of underground or rail urban logistics is taking over [18].

According to Ruggieri et al., 2021, it is important to integrate electric mobility to reduce the use of energy sources and to reduce urban pollution [19].

The axes are therefore diverse and vary from one economy or culture to another. However, from this analysis, the most frequent axes are as follows (Figure 5) [9, 20-24]:

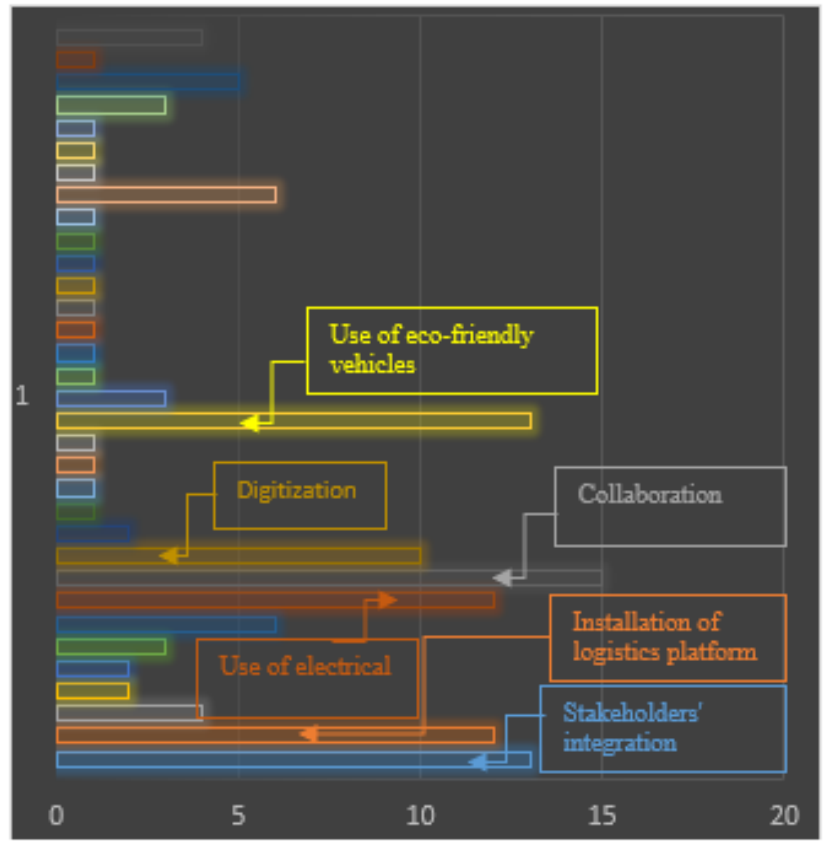

Figure 5. Most important axes of urban logistics

\subsection{Urban logistics' distribution systems}

From the elements of our database, we can deduce that the transport of goods from the manufacturer to the end customer is done through one of the three types of distribution systems at the urban level [25-29]:

1-Cyclic transport: bicycles, scooters, cargo-bikes, bullitbikes... are the most efficient means of transport as long as they can access certain narrow areas and do not endanger people's lives in any way.

2-Intelligent or electric transport: These are transport systems characterized by the involvement of new telecommunications and computer technologies in order to make the system capable of acting and adapting to real contexts. -Electric vans \& bicycles, E-tricycles.

3-Common transport (Goods \& People): This concerns taking into account the unused capacities of people transporting people, and the possibility of integrating both man and freight within the same distribution system. -Metro, Trains \& Buses.

Table 3 highlights the positive and negative points of each type of transport:

Table 3. Types of transport analysis

\begin{tabular}{|c|c|c|c|}
\hline Type of transport & Advantages & Disadvantages & Cost \\
\hline Cyclic transport & $\begin{array}{l}\text { Does not endanger passengers } \\
\text { Can serve narrow areas } \\
\text { Can perform several alternations }\end{array}$ & $\begin{array}{c}\text { Reduced speed } \\
\text { No safety for the driver } \\
\text { Requires unleveled, non-rocky infrastructure } \\
\text { Reduced volume capacity }\end{array}$ & $\begin{array}{l}\text { Very affordable } \\
\text { transport cost }\end{array}$ \\
\hline $\begin{array}{l}\text { Intelligent } \\
\text { transportation }\end{array}$ & $\begin{array}{l}\text { Continuous tracking of vehicle } \\
\text { routes } \\
\text { Adaptation to the needs of each } \\
\text { delivery }\end{array}$ & $\begin{array}{c}\text { Battery charging problems } \\
\text { Vehicles requiring regular and expensive maintenance } \\
\text { Not suitable for all cultures }\end{array}$ & Very high cost \\
\hline Public transport & $\begin{array}{l}\text { Use of existing means of public } \\
\text { transport } \\
\text { Delivery according to public } \\
\text { transport routes }\end{array}$ & $\begin{array}{c}\text { Distribution in several back and forth } \\
\text { Need to have containers for goods } \\
\text { Vehicles well equipped according to the nature of the } \\
\text { materials to be transported }\end{array}$ & Relatively high cost \\
\hline
\end{tabular}


It is significant to point that the optimal solution is a ternary assortment that will put forward sustainability -environment and safety-, then efficiency and finally cost.

In order to correctly choose the most suitable means of transport, it becomes imperative to point out that the three types of distribution systems can involve the customer /consumer by inviting him or not to actively participate reciprocally in the collection of his own merchandise according to three possibilities as well $[4-24,30]$ :

1-The HYBRID system: a first transfer is made to a forwarding agent who is responsible for keeping the product until the consumer comes to collect it from the intermediate site.

2-The PULL system: The customer at this level is a primary link in the distribution chain, because he will be responsible for recovering the product by himself using his own resources.

3-The PUSH system: The consumer is not involved in the delivery process; the product is sent to the customer by the company directly or by another transport agent. 4:

In the following an analysis of distribution systems in Table

Table 4. Systems of distribution analysis

\begin{tabular}{|c|c|c|}
\hline System & Advantages & Disadvantages \\
\hline Hybrid & $\begin{array}{l}\text { Recovery of the goods } \\
\text { according to the consumer's } \\
\text { availability } \\
\text { Partial reduction in transport } \\
\text { costs for the benefit of } \\
\text { companies }\end{array}$ & $\begin{array}{l}\text { Consumer resistance } \\
\text { Intermediate storage } \\
\text { costs }\end{array}$ \\
\hline Pull & $\begin{array}{l}\text { Recovery of the goods } \\
\text { according to the consumer's } \\
\text { availability } \\
\text { Total reduction in transport } \\
\text { costs for the benefit of } \\
\text { companies }\end{array}$ & $\begin{array}{l}\text { Additional transport } \\
\text { costs } \\
\text { Non-optimal route }\end{array}$ \\
\hline Push & $\begin{array}{l}\text { Transport subcontracted to a } \\
\text { transport agent }\end{array}$ & $\begin{array}{c}\text { Multiplicity of } \\
\text { distributions } \\
\text { Additional activity for } \\
\text { manufacturers }\end{array}$ \\
\hline
\end{tabular}

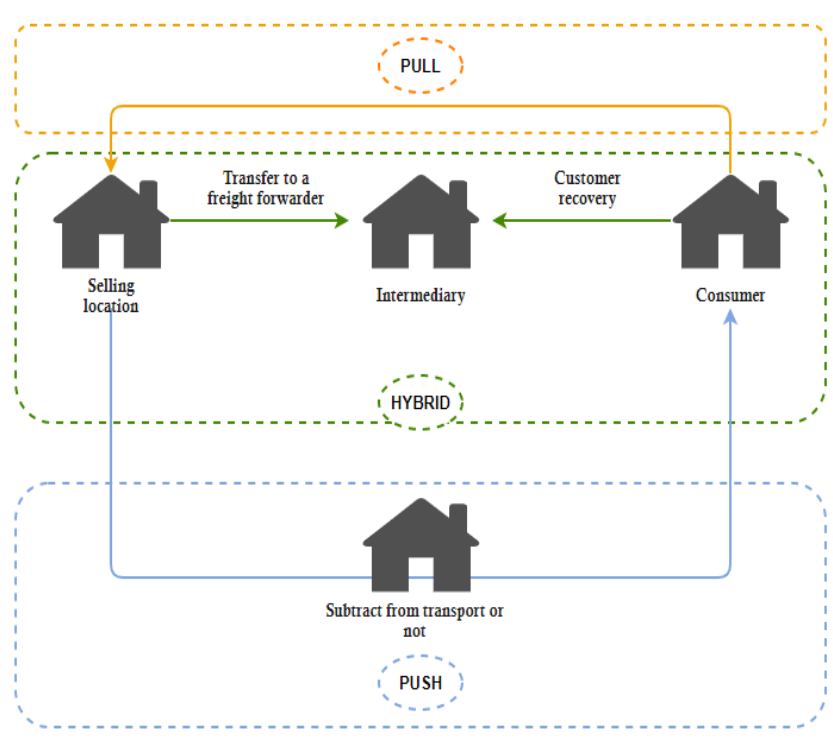

Figure 6. Systems of distribution chart
The choice of distribution system involves a whole panoply of elements (Figure 6). First, it is associated with the mode of transport chosen for the transport of goods. Second, the culture and resistance of the parties concerned play a very important role in the choice of systems: A less expensive solution may not necessarily be accepted by the customer. Third, the costs generated by the movement of customers are certainly not at the expense of the carrier, but always present an excessive load in the event that the customer has to make long journeys.

\subsection{Urban logistics' segments}

We define urban logistics activity by a set of dependencies and correlations.

The segmentation of urban logistics parts aims to separate the different actors in order to identify each one to know the expectations and the limits of each link.

Similar to the segmentation of the classic value chain that deals with both upstream and downstream side of the line; urban logistics is made up of an assortment of sub-elements that we present as Figure 7 [31-36].

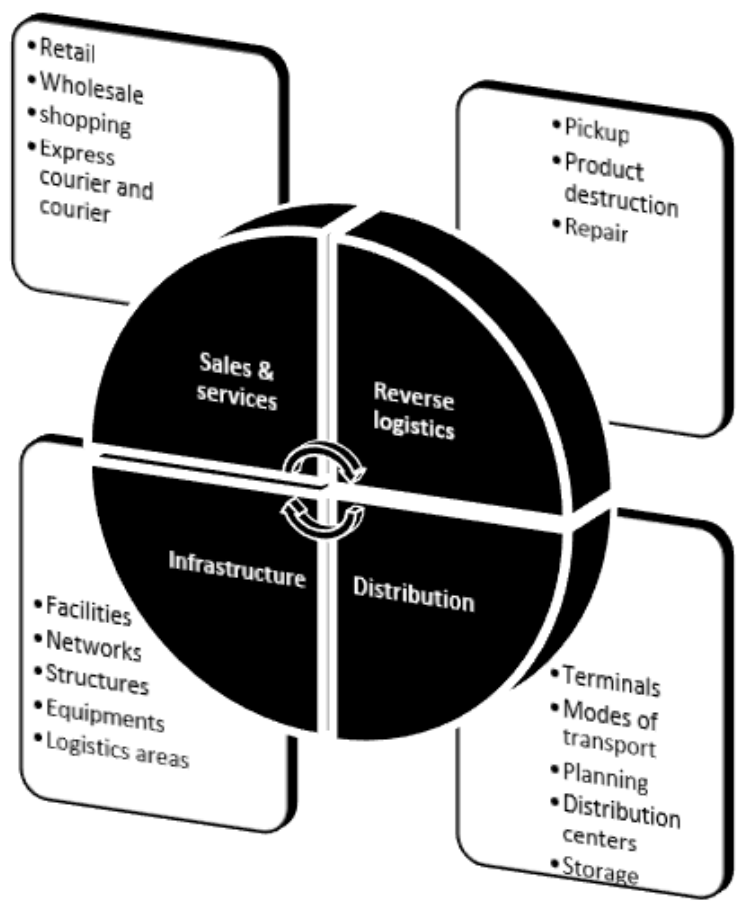

Figure 7. Representation of urban logistics segments

The major contribution of segmentation is the separation of units, so to know at what level exactly to proceed to optimize the overall activity of urban logistics.

\subsection{Stakeholders}

All mobility policies, which implicitly or explicitly include the word "sustainability or resilience", raise questions about what sustainable mobility correctly represents, how it should be managed by cities, who will intervene at the level of this decision-making and who will it affect.

Stakeholders can be defined as the parties affected by decisions made within the framework of urban logistics and who may or may not have a fundamental opinion in this decision-making (Table 5).

This is a non-exhaustive list of links, which includes at least the following actors $[9,15,32,37-55]$ : 
Table 5. Stakeholders analysis

\begin{tabular}{|c|c|c|c|}
\hline Actors & Dockets & Definitions & Interests \\
\hline Sender & $\begin{array}{l}\text { Commitment } \\
\text { Vehicle safety }\end{array}$ & $\begin{array}{l}\text { Organization ensuring in the proper name of the company, } \\
\text { the transport of goods for an ordering customer by carrying } \\
\text { out the transport or by subcontracting it }\end{array}$ & $\begin{array}{c}\text { Customer satisfaction } \\
\text { Business satisfaction } \\
\text { Reduction of costs \& } \\
\text { delays } \\
\end{array}$ \\
\hline Logistic provider & Commitment & $\begin{array}{l}\text { Company providing support for logistics flows in terms of } \\
\text { transport and storage }\end{array}$ & $\begin{array}{l}\text { Dispatching of deliveries } \\
\text { Consolidation of freight } \\
\text { with the same destination }\end{array}$ \\
\hline $\begin{array}{l}\text { Reversed logistics } \\
\text { operator }\end{array}$ & Vehicle safety & $\begin{array}{l}\text { Operator who will manage the return, collection, repair, } \\
\text { destruction and disposal of products }\end{array}$ & $\begin{array}{l}\text { Customer satisfaction } \\
\text { Quick and efficient } \\
\text { pickup }\end{array}$ \\
\hline Warehouseman & $\begin{array}{l}\text { Good handling of } \\
\text { handling vehicles }\end{array}$ & $\begin{array}{l}\text { Operator responsible for the management of storage, } \\
\text { rotation, movement and arrangement of goods }\end{array}$ & $\begin{array}{l}\text { Optimal stock level } \\
\text { Good stock rotation }\end{array}$ \\
\hline Local authority & $\begin{array}{l}\text { Power } \\
\text { Responsibility }\end{array}$ & $\begin{array}{c}\text { Competent authority covering the transport needs of an } \\
\text { urban agglomeration }\end{array}$ & $\begin{array}{l}\text { Ensuring a good quality } \\
\text { of life for citizens } \\
\text { Ensuring the safety of } \\
\text { people } \\
\text { Ensure the protection of } \\
\text { the environment } \\
\text { Maintenance of } \\
\text { infrastructure }\end{array}$ \\
\hline Cargo carrier & Respect for infrastructures & $\begin{array}{l}\text { Company responsible for moving freight (goods) from one } \\
\text { location to another according to a mode of transport scheme } \\
\text { based on the nature of the infrastructure }\end{array}$ & $\begin{array}{c}\text { Safety of transported } \\
\text { goods } \\
\text { Fast delivery to the } \\
\text { customer } \\
\text { Cost reduction } \\
\end{array}$ \\
\hline Industrial & $\begin{array}{l}\text { Resistance to durability } \\
\text { Responsibility to } \\
\text { customers and citizens }\end{array}$ & Production logistics & $\begin{array}{l}\text { Fast delivery to the } \\
\text { customer } \\
\text { Reduced transport costs } \\
\text { Condensed deadlines }\end{array}$ \\
\hline Driver & $\begin{array}{c}\text { Responsibility towards } \\
\text { citizens }\end{array}$ & $\begin{array}{l}\text { Intermediary between customers and manufacturers, it } \\
\text { ensures the conduction of the delivery vehicle }\end{array}$ & $\begin{array}{l}\text { Safety of goods and } \\
\text { people transported }\end{array}$ \\
\hline Resident & Respect the environment & Natural person belonging to a given urban territory & $\begin{array}{l}\text { Living in an unpolluted } \\
\text { environment } \\
\text { security }\end{array}$ \\
\hline Regulator & Competence to optimize & $\begin{array}{l}\text { Agent whose role is to ensure optimal management of } \\
\text { freight, vehicle and passenger movements }\end{array}$ & $\begin{array}{l}\text { Travel optimization } \\
\text { Reduction of energy } \\
\text { consumed }\end{array}$ \\
\hline Dealer & $\begin{array}{c}\text { Proficiency } \\
\text { Authority } \\
\end{array}$ & Administration granting transport authorizations & $\begin{array}{l}\text { Safety of goods and } \\
\text { people }\end{array}$ \\
\hline Planner & $\begin{array}{l}\text { Ability to plan for the } \\
\text { short, long and medium } \\
\text { terms. }\end{array}$ & $\begin{array}{c}\text { Resource and needs match manager, transport and } \\
\text { production planner }\end{array}$ & Route optimization \\
\hline Operations officer & $\begin{array}{l}\text { Good attitude towards } \\
\text { customers and } \\
\text { manufacturers }\end{array}$ & $\begin{array}{l}\text { Intermediary between the driver and the customer, he uses } \\
\text { all human and material resources }\end{array}$ & $\begin{array}{l}\text { Good progress of } \\
\text { transport operations }\end{array}$ \\
\hline Customer & $\begin{array}{l}\text { Refusal to join the routing } \\
\text { process }\end{array}$ & $\begin{array}{c}\text { Receiver of the product, which may or may not be the final } \\
\text { consumer }\end{array}$ & $\begin{array}{l}\text { Reduced acquisition } \\
\text { prices }\end{array}$ \\
\hline Consumer & $\begin{array}{l}\text { Refusal to join the routing } \\
\text { process }\end{array}$ & End customer who will consume the product & Advantageous rates \\
\hline
\end{tabular}

\section{CONCLUSION}

In this article, we have discussed some of the important aspects related to urban logistics. While developing our analysis, we felt it necessary to recall a few key elements such as the pillars, distribution modes and systems or even urban logistics segments.

The objective of this research is to know which areas of sustainable urban logistics must be prioritized to make the whole process accomplished.

In urban logistics, an optimal freight distribution process requires the bundling of several factors. Within the framework of stakeholder involvement, private and public actors must cooperate with each other and use their resources jointly. The means of transport should be chosen according to the urban context treated, which therefore depends on the volumes of transport, infrastructure, the nature of the city as well as the investment cost envisaged. The installation of logistics platforms is also an element to be taken into consideration since it forms recovery hubs and will break the monotony of journeys.

The future for urban logistics is the contribution of logistics 4.0 in terms of digitization and digitalization, in a short time the entire chain will be digitalized and will be able to work intelligently independently. 


\section{REFERENCES}

[1] Kull, T.J., Boyer, K., Calantone, R. (2007). Last-mile supply chain efficiency: an analysis of learning curves in online ordering. International Journal of Operations \& Production Management, 27(4): 409-434. https://doi.org/10.1108/01443570710736985

[2] Macharis, C., Melo, S. (2011). City Distribution and Urban Freight Transport. https://doi.org/10.4337/9780857932754

[3] Dündar, H., Ömürgönülşen, M., Soysal, M. (2021). A review on sustainable urban vehicle routing. Journal of Cleaner Production, 285: 125444. https://doi.org/10.1016/j.jclepro.2020.125444

[4] Navarro, C., Roca-Riu, M., Furió, S., Estrada, M. (2016). Designing new models for energy efficiency in urban freight transport for smart cities and its application to the Spanish case. Transportation Research Procedia, 12: 314-324. https://doi.org/10.1016/j.trpro.2016.02.068

[5] Schliwa, G., Armitage, R., Aziz, S., Evans, J., Rhoades, J. (2015). Sustainable city logistics - Making cargo cycles viable for urban freight transport. Research in Transportation Business \& Management, 15: 50-57. https://doi.org/10.1016/j.rtbm.2015.02.001

[6] Nürnberg, M. (2019). Analysis of using cargo bikes in urban logistics on the example of Stargard. Transportation Research Procedia, 39: 360-369. https://doi.org/10.1016/j.trpro.2019.06.038

[7] Ruesch, M., Todesco, P., Hegi, P. (2020). A positive planning approach to secure logistics facilities in urban areas. Transportation Research Procedia, 46: 69-76. https://doi.org/10.1016/j.trpro.2020.03.165

[8] Gatta, V., Marcucci, E., Le Pira, M. (2017). Smart urban freight planning process: integrating desk, living lab and modelling approaches in decision-making. European Transport Research Review, 9(3). https://doi.org/10.1007/s12544-017-0245-9

[9] Tian, Z., Zhong, R.Y., Vatankhah Barenji, A., Wang, Y.T., Li, Z., Rong, Y. (2020). A blockchain-based evaluation approach for customer delivery satisfaction in sustainable urban logistics. International Journal of Production Research, 59(7): 2229-2249. https://doi.org/10.1080/00207543.2020.1809733

[10] Giret, A. (2019). Smart and sustainable urban logistic applications aided by intelligent techniques. Service Oriented Computing and Applications, 13(3): 185-186. https://doi.org/10.1007/s11761-019-00271-z

[11] Kauf, S. (2016). City logistics - A Strategic Element of Sustainable Urban Development. Transportation Research Procedia, 16: 158-164. https://doi.org/10.1016/j.trpro.2016.11.016

[12] Quak, H., Lindholm, M., Tavasszy, L., \& Browne, M. (2016). From freight partnerships to city logistics living labs - giving meaning to the elusive concept of living labs. Transportation Research Procedia, 12: 461-473. https://doi.org/10.1016/j.trpro.2016.02.080

[13] Morfoulaki, M., Kotoula, K., Stathacopoulos, A., Mikiki, F., \& Aifadopoulou, G. (2016). Evaluation of specific policy measures to promote sustainable urban logistics in small-medium sized cities: The case of Serres, Greece. Transportation Research Procedia, 12: 667-678. https://doi.org/10.1016/j.trpro.2016.02.020

[14] Cossu, P. (2016). Clean last mile transport and logistics management for smart and efficient local governments in
Europe. Transportation Research Procedia, 14: 15231532. https://doi.org/10.1016/j.trpro.2016.05.117

[15] Lagorio, A., Pinto, R., Golini, R. (2017). Urban Logistics Ecosystem: a system of system framework for stakeholders in urban freight transport projects. IFACPapersOnLine, 50(1): 7284-7289. https://doi.org/10.1016/j.ifacol.2017.08.1402

[16] Pimentel, C., Alvelos, F. (2018). Integrated urban freight logistics combining passenger and freight flows mathematical model proposal. Transportation Research Procedia 30: 80-89. https://doi.org/10.1016/j.trpro.2018.09.010

[17] Bergmann, F.M., Wagner, S.M., Winkenbach, M. (2020). Integrating first-mile pickup and last-mile delivery on shared vehicle routes for efficient urban e-commerce distribution. Transportation Research Part B: Methodological, 131: 26-62. https://doi.org/10.1016/j.trb.2019.09.013

[18] Yue, S., Wang, Y., Zhao, M., Liu, Y. (2021). Research on the Feasibility and distribution mode of urban logistics distribution by Rail Transit. Journal of Physics: Conference $\quad$ Series, $\quad 1827(1)$ : 012101. https://doi.org/10.1088/1742-6596/1827/1/012101

[19] Ruggieri, R., Ruggeri, M., Vinci, G., Poponi, S. (2021). Electric mobility in a smart city: European overview. Energies, 14(2): 315. https://doi.org/10.3390/en14020315

[20] Farvaresh, H., Shahmansouri, S. (2020). A coalition structure algorithm for large-scale collaborative pickup and delivery problem. Computers \& Industrial Engineering, 149: 106737 https://doi.org/10.1016/j.cie.2020.106737

[21] Kumar, S., Bharj, R.S. (2020). Solar hybrid e-cargo rickshaw for urban transportation demand in India. Transportation Research Procedia, 48: 1998-2005. https://doi.org/10.1016/j.trpro.2020.08.228

[22] Lin, Y.H., Wang, Y., He, D., Lee, L.H. (2020). Last-mile delivery: Optimal locker location under multinomial logit choice model. Transportation Research Part E: Logistics and Transportation Review, 142: 102059. https://doi.org/10.1016/j.tre.2020.102059

[23] Jiang, B., Fan, Z.P. (2020). Optimal allocation of shared parking slots considering parking unpunctuality under a platform-based management approach. Transportation Research Part E: Logistics and Transportation Review, 142: 102062. https://doi.org/10.1016/j.tre.2020.102062

[24] Drop, N., Garlińska, D. (2021). Evaluation of intelligent transport systems used in urban agglomerations and intercity roads by professional truck drivers. Sustainability, 13(5): 2935 https://doi.org/10.3390/su13052935

[25] Szymczyk, K., Kadłubek, M. (2019). Challenges in general cargo distribution strategy in urban logistics comparative analysis of the biggest logistics operators in EU. Transportation Research Procedia, 39: 525-533. https://doi.org/10.1016/j.trpro.2019.06.054

[26] Tahami, H., Rabadi, G., Haouari, M. (2020). Exact approaches for routing capacitated electric vehicles. Transportation Research Part E: Logistics and Transportation Review, 144: 102126. https://doi.org/10.1016/j.tre.2020.102126

[27] Crainic, T.G., Gendreau, M., Jemai, L. (2020). Planning hyperconnected, urban logistics systems. Transportation 
Research Procedia, 47: 35-42. https://doi.org/10.1016/j.trpro.2020.03.070

[28] Nathanail, E., Gogas, M., Adamos, G. (2016). Smart interconnections of interurban and urban freight transport towards achieving sustainable city logistics. Transportation Research Procedia, 14: 983-992. https://doi.org/10.1016/j.trpro.2016.05.078

[29] Zhang, Z., Tafreshian, A., Masoud, N. (2020). Modular transit: Using autonomy and modularity to improve performance in public transportation. Transportation Research Part E: Logistics and Transportation Review, 141: 102033. https://doi.org/10.1016/j.tre.2020.102033

[30] Russo, F., Comi, A. (2020). Behavioural simulation of urban goods transport and logistics: The integrated choices of end consumers. Transportation Research Procedia, 46:

$165-172$ https://doi.org/10.1016/j.trpro.2020.03.177

[31] Schöder, D., Ding, F., Campos, J.K. (2016). The Impact of E-Commerce Development on Urban Logistics Sustainability. Open Journal of Social Sciences, 04(03): 1-6. https://doi.org/10.4236/jss.2016.43001

[32] Wolbertus, R., Jansen, S., Kroesen, M. (2020). Stakeholders' perspectives on future electric vehicle charging infrastructure developments. Futures, 123: 102610. https://doi.org/10.1016/j.futures.2020.102610

[33] Bhasker, A., Sarmah, S.P., Kim, T. (2019). Collaborative last-mile delivery and pick-up in city logistics. International Journal of Logistics Systems and Management, 34(4):

533. https://doi.org/10.1504/ijlsm.2019.103518

[34] Gusmão, A.C.S.de, Ribeiro, P.C.M. (2020). Guidelines for the efficiency of urban goods distribution: The Brazilian case. Case Studies on Transport Policy, 8(4): 1478-1488. https://doi.org/10.1016/j.cstp.2020.10.013

[35] Karakikes, I., Nathanail, E. (2017). Simulation techniques for evaluating smart logistics solutions for sustainable urban distribution. Procedia Engineering, 178: $569-578$ https://doi.org/10.1016/j.proeng.2017.01.110

[36] He, P., He, Y., Xu, H. (2020). Buy-online-and-deliverfrom-store strategy for a dual-channel supply chain considering retailer's location advantage. Transportation Research Part E: Logistics and Transportation Review, 144: 102127. https://doi.org/10.1016/j.tre.2020.102127

[37] Fredriksson, A., Janné, M., Nolz, P., de Radiguès de Chennevière, P., van Lier, T., Macharis, C. (2021). Creating stakeholder awareness in construction logistics by means of the MAMCA. City and Environment Interactions, 11:

100067. https://doi.org/10.1016/j.cacint.2021.100067

[38] Liang, T., Wang, H. (2021). Consumer decision-making and smart logistics planning based on FPGA and convolutional neural network. Microprocessors and Microsystems, 80 : 103628 https://doi.org/10.1016/j.micpro.2020.103628

[39] Leyerer, M., Sonneberg, M.O., Heumann, M., Breitner, M.H. (2020). Shortening the last mile in urban areas: optimizing a smart logistics concept for e-grocery operations. Smart Cities, 3(3): 585-603. https://doi.org/10.3390/smartcities3030031

[40] Mor, A., Speranza, M.G., Viegas, J.M. (2020). Efficient loading and unloading operations via a booking system. Transportation Research Part E: Logistics and
Transportation Review, 141:

102040. https://doi.org/10.1016/j.tre.2020.102040

[41] Yang, F., Dai, Y., Ma, Z.J. (2020). A cooperative rich vehicle routing problem in the last-mile logistics industry in rural areas. Transportation Research Part E: Logistics and Transportation Review, 141: 102024. https://doi.org/10.1016/j.tre.2020.102024

[42] Gogas, M., Adamos, G., Nathanail, E. (2017). Assessing the performance of intermodal city logistics terminals in Thessaloniki. Transportation Research Procedia, 24: 1724. https://doi.org/10.1016/j.trpro.2017.05.061

[43] Gonçalves, L.A.P.J., Ribeiro, P.J.G. (2020). Resilience of urban transportation systems. Concept, characteristics, and methods. Journal of Transport Geography, 85: 102727. https://doi.org/10.1016/j.jtrangeo.2020.102727

[44] Groß, P.O., Ehmke, J.F., Mattfeld, D.C. (2020). Interval travel times for robust synchronization in city logistics vehicle routing. Transportation Research Part E: Logistics and Transportation Review, 143: 102058. https://doi.org/10.1016/j.tre.2020.102058

[45] Hammami, F. (2020). The impact of optimizing delivery areas on urban traffic congestion. Research in Transportation Business \& Management, 37: 100569. https://doi.org/10.1016/j.rtbm.2020.10

[46] He, M., Sun, L., Zeng, X., Liu, W., Tao, S. (2020). Node layout plans for urban underground logistics systems based on heuristic Bat algorithm. Computer Communications, 154: 465-480. https://doi.org/10.1016/j.comcom.2020.02.075

[47] Hu, W., Dong, J., Hwang, B., Ren, R., Chen, Z. (2020). Hybrid optimization procedures applying for twoechelon urban underground logistics network planning: A case study of Beijing. Computers \& Industrial Engineering, 144 : 106452. https://doi.org/10.1016/j.cie.2020.106452

[48] Ke, J., Yang, H., Zheng, Z. (2020). On ride-pooling and traffic congestion. Transportation Research Part B: Methodological, 142: 213-231. https://doi.org/10.1016/j.trb.2020.10.003

[49] Lozano, A., Cantillo, V., Holguín-Veras, J. (2020). Special issue on "Urban transportation sustainability: Experiences and innovative approaches." Transportation Research Part A: Policy and Practice, 137: 325. https://doi.org/10.1016/j.tra.2020.05.023

[50] Masik, G., Sagan, I., Scott, J.W. (2021). Smart Smart City strategies and new urban development policies in the Polish context. Cities, 108: 102970. https://doi.org/10.1016/j.cities.2020.102970

[51] Matusiewicz, M. (2019). SULP (Sustainable Urban Logistics Plan) as a tool for shaping sustainable urban logistics: A review of European projects supporting the creation of SULP. Transport Economics and Logistics, 84: 71-78. https://doi.org/10.26881/etil.2019.84.06

[52] Alho, A., Bhavathrathan, B.K., Stinson, M., Gopalakrishnan, R., Le, D.T., Ben-Akiva, M. (2017). A multi-scale agent-based modelling framework for urban freight distribution. Transportation Research Procedia, 27: 188-196. https://doi.org/10.1016/j.trpro.2017.12.138

[53] Chu, X., Liu, J., Ren, L., Gong, D. (2020). Optimal contract design with a common agency in last-mile logistics. Transportation Research Part E: Logistics and Transportation Review, 139: 101956. https://doi.org/10.1016/j.tre.2020.101956 
[54] De Bok, M., Tavasszy, L., Thoen, S. (2020). Application of an empirical multi-agent model for urban goods transport to analyze impacts of zero emission zones in The Netherlands. Transport Policy. https://doi.org/10.1016/j.tranpol.2020.07.010
[55] Gerlach, J., Richter, N., Becker, U.J. (2016). Mobility indicators put to test - German strategy for sustainable development needs to be revised. Transportation Research Procedia, 14: 973-982. https://doi.org/10.1016/j.trpro.2016.05.077 